\title{
The Professional Identity of Adjunct Faculty: Exploratory Study at a Private University in the UAE
}

\author{
Taghreed Ibrahim Masri ${ }^{1}$ \\ ${ }^{1}$ Faculty of Communication, Arts and Sciences, Canadian University of Dubai, Dubai, United Arab Emirates \\ Correspondence: Taghreed Masri, Faculty of Communication, Arts and Sciences, Canadian University of Dubai, \\ Dubai, United Arab Emirates. Tel: 9714-709-6855. E-mail: taghreed.masri@cud.ac.ae
}

Received: July 28, 2018 Accepted: September 11, 2018 Online Published: September 13, 2018

doi: 10.5539/elt.v11n10p16 URL: http://doi.org/10.5539/elt.v11n10p16

\begin{abstract}
Professional identity has recently made its way as a concept that has become a central theme in teachers' professionalism. However, adjunct faculty professional identity and development have not been given enough interest in literature despite their increasing contribution in higher education. The purpose of this study was to assess adjuncts' perceptions of their identity. It also aimed to examine what institutional professional development they receive and the effect of its presence or absence on their professional identity. Four semi-structured interviews were conducted with four adjunct faculty in the Department of Writing Studies at a university in the UAE. Results showed that adjunct faculty have dilemma making sense of their professional selves due to being perceived differently by their students, colleagues, administrators and themselves. Results also showed that adjuncts are vulnerable, insecure, and embarrassed to declare their identity to their students. In addition, findings revealed that they do not get institutional professional development opportunities that they need and that ignoring their professional development threatens the quality of teaching and the reputation of the institution they work in.
\end{abstract}

Keywords: professional identity, marginalization, equity, self-esteem, adjunct, access

\section{Introduction}

\subsection{Nature of the Problem}

Professional identity is a relatively new concept, "an area that has not been researched in any great depth among the professions let alone in higher education" (Clarke et al., 2013, p. 9). However, only recently, it has gained ground in literature (Beijaard, 2013; Clarke, Hyde, \& Drennan, 2013; Cojocnean, 2013; Hong, 2010; Kelchtermans; 2009, MacLure, 1993; Thomas \& Beauchamp, 2010; Tsui, 2007). Many studies are nowadays interested in analyzing the teachers' professional identity because it has been acknowledged that understanding their professional identity is essential for gaining insight into their professional lives' essential aspects such as their self-efficacy, motivation, emotional well-being, job satisfaction, commitment, and effectiveness (Day, 2007; Hong, 2010). Thus, we need to have a clearer understanding of who they are, what professional, cultural, political, and individual identities they claim or are assigned to them (Varghese, Morgan, Johnston, \& Johnson, 2005). The importance of studying teachers' identity is further emphasized by Kelchtermans (2009) who states that "the person of the teacher is an essential element in what constitutes professional teaching and therefore needs careful conceptualization" (p. 257).

\subsection{Importance of the Problem}

Despite the centrality of professional development in adjuncts' professional lives and identity formation, the literature suggests that any discussion of the real and suitable professional development for adjunct faculty is mostly a farfetched dream (Bojarczyk, 2008; Leslie \& Gappa, 1993; Lusiak, 2011; Tsui, 2007). It indicates that despite the adjuncts' apparent need for professional development, it is still a neglected endeavor (Bojarczyk, 2008). Gappa and Leslie (1993) profess that these "faculty members are hired to teach and have limited status and respect, little support for professional development, low salaries, little access to fringe benefits, and no job security" (as cited in Gappa, 2008, p. 52). This view is shared by Lusiak (2011) who asserts that the ladder of advancement doesn't really exist for adjuncts whose ultimate wish is to have a job waiting for them the following semester. Adjunct faculty are often at "the bottom of the priority list when opportunities for 
professional development and growth become available" (Gappa \& Leslie, 1993, p. 262). This all has contributed to creating "an identity of nonparticipation and marginality" (Wenger, as cited in Tsui, p.661). The study will seek to demystify the lives of the adjunct faculty in the DWS (Department of Writing Studies) at a university in the UAE.

\subsection{Literature Review}

\subsubsection{Professional Identity}

Despite the emergence of professional identity as a separate area in literature, it has been defined differently by different researchers or has not been defined at all (Beijaard et al., 2004). Hong clarifies, "Not enough research has been accumulated to generate indisputable agreement on the definition and core tenets of teachers' professional identity" (2010, p. 1531). It is still "an unclear concept in the sense of what, and to what extent, things are integrated in such an identity" (Beijaard et al., 2004, p. 108). After analyzing several studies on professional identity, Beijaard et el. found out that the studies that defined professional identity highlighted different aspects. However, what researchers agree on, though, is that professional identity is not a stable product, but rather a continually changing, active, and an ongoing process. Beijaard et al. pointed out that "most of the researchers saw professional identity as an ongoing process of integration of the personal and the professional sides of becoming and being a teacher" (2004, p. 119). Those researchers suggested that professional identity is not a stable entity but complex, dynamic, ever-changing and cannot be conceptualized as fixed, stable, or unitary (Beijaard et al., 2004). This recognition of its evolving nature has rejected an essentialist and monolithic understanding of self and identity as static (Kelchtermans, 2005).

Many researchers have emphasized reflection and self-reflection in their definition of professional identity (Connelly \& Clandinin, 1999; Kelchtermans, 2005; Lasky, 2005; Simon-Maeda, 2004). Lasky (2005) defines teacher professional identity as "how teachers define themselves to themselves and to others" (p. 902). This definition occurs through story-telling which Connelly and Clandinin (1999) refer to in terms of "stories to live by" (p. 4). These stories are expressions of teachers' identity which only appears in the act of telling or self-reflection because teachers merge their personal and professional selves when they talk about their professional lives (Kelchtermans, 2005). Beijaard et al. (2004) point out, "Through storytelling, teachers engage in narrative 'theorizing' and, based on that, teachers may further discover and shape their professional identity resulting in new or different stories" (p. 121). These stories that "teachers tell and live by are discursive displays of professional and personal beliefs situated in specific social worlds and realized through interactions with others" (Simon-Maeda, 2004, p. 429).

\subsubsection{Professional Identity Components}

The components of professional identity are best described and analysed by the leading scholar, Kelchtermans whose analysis will be the framework of my study. Thus, this section is devoted to a review on his work on professional identity components. Kelchtermans (2009) uses 'professional self-understanding' instead of 'professional identity' because he believes that the use of identity might be associated with the idea of having a static essence which might implicitly ignore or deny its dynamic and biographical nature. Self-understanding, according to Kelchtermans, refers to the understanding one has of his self as a product as well as an ongoing process of making sense of the experiences and their impacts on the self.

Kelchtermans (2009) identifies five components that make up teachers' self-understanding which are "self-image, self-esteem, job motivation, task perception and future perspective" (p. 261). The self-image is not only based on how teachers perceive themselves and who they are as teachers, but also on what others mirror back to them. Therefore, the self-image is "strongly influenced by the way one is perceived by others" (p. 262). The second component is self-esteem which refers to the teachers' sense of appreciation of their actual job performance. Teachers, according to Kelchtermans, consider students' feedback the most important and relevant. Nias also considers that the classroom is the teachers' "main site for their self-esteem and fulfilment, and so too for their vulnerability" (1996, p. 297). Positive self-esteem, according to Kelchtermans, is crucial for teachers to feel at ease in the job, experience job satisfaction and a sense of fulfilment, for their well-being as teachers. However, positive self-evaluations are not stable but are fragile, fluctuating in time and have to be re-established over time. They are also deeply affected by negative public judgments that may leave devastating impact on them. Intertwined with self-esteem is the task-perception. When teachers perceive themselves as proper teachers, they will have self-esteem. Kelchtermans states, "The task perception encompasses deeply held beliefs about what constitutes good education, about one's moral duties and responsibilities in order to do justice to students" (p. 262). When these beliefs are questioned, teachers feel that their own person is called into question. That is why when institutional values contradict their task-perception, teachers' self-esteem and job satisfaction will be 
deeply affected. The job motivation refers to the drives or motives behind teachers' decisions to be teachers or to stay in teaching or give it up. The task perception and the working conditions are crucial determinants for the job motivation. It also develops over time. The last component is the future perspective which refers to the teacher's expectations about future in the job. This component reflects the dynamic nature of the self-understanding.

Lasky (2005) adds one more component to teachers' professional identity which is vulnerability which he defines as "a multidimentional, multifaceted emotional experience that ... can be influenced by the way people perceive their present situation as it interacts with their identity, beliefs, values, and sense of competence" (p. 901). Lasky suggests that it is a fluctuating sense of being intensified or changed with critical incidents. In collaborative, friendly environments, teachers willingly open themselves to any possible embarrassment or emotional pain because they perceive it beneficial for them and for others which facilitates learning and teaching. In Lasky's words, the teacher "feels safe in his or her environment to take the risk of losing face and experiencing loss or pain" (p. 901). However, vulnerability develops due to feeling powerless, betrayed, and defenseless in situations of fear or anxiety. When teachers feel they have no control over their immediate context or forced to do things that are not consistent with their beliefs and values, they don't open up emotionally but withdraw and close up and develop defensive mechanism in attempt to preserve the status quo which inhibits learning, trust building, and collaboration (Lasky, 2005, Kelchtermans, 2005). Kelchtermans (2005) emphasizes that "basic structure in vulnerability is always one of feeling that one's professional identity and moral integrity ... are questioned and that valued workplace conditions are thereby threatened or lost" $(2005$, p. 997). Thus, the context is of profound importance as "vulnerability is mediated by the context ... and is directly linked to teachers' identity" (Kelchtermans, 2005, p. 997).

\subsubsection{Adjunct Faculty in Higher Education}

Adjunct faculty are referred to in the literature as contingent, part-timers, non-tenure-eligible, adjuncts (Gappa, 2008) and many other titles depending on the institution for which they teach (Lyons, 2007). The problem with these titles is that none of them "seems completely appropriate" (Lyons, 2007, p. 2). Erdman (2011) considers these descriptors "misnomers" and states that "this misnaming is deliberately perpetuated ... in order to keep adjunct faculty in their place" (p. 6). However, despite the fact that these names do not do any justice to these instructors as they emphasize the negative side of their work, in this paper, I will refer to them as adjuncts because it is their descriptor at the university where the study took place.

However, misnaming this category of instructors in higher education does not reflect their huge presence in the world of academia. Lyons (2007) states that most colleges and universities cannot function efficiently or effectively without the role that adjunct faculty play in the instructional system. Recently, they have become a permanent fixture on the academic landscape to the extent that they are so close of becoming the majority providers of instruction in American higher education (Bojarczyk, 2008). Korkki (2018) pointed out that "tenure-track positions are shrinking at colleges and universities." This 'adjunctification' phenomenon, as described by Magness (2017), is becoming a familiar concern for recent Phd graduates who are afraid that "tenure track faculty postions [are] replaced by part-time adjuncts as a cost-saving measure. As a result, people with advanced degrees have found themselves in lower-paying adjunct positions." This increasing reliance on adjuncts came, according to Bojarczyk (2008), as a result of the changing financial and demographic pressures which are forcing universities to increase their dependence on adjunct faculty (Bojarczyk, 2008). Osterag (1991) stated that the pressure in higher education to hire adjuncts is due to budgetary constraints that make them attractive option since their duties begin and end in the classroom, are denied employee benefits, and most importantly due to the flexibility they provide when there is uncertainty about student enrollments (as cited in Bojarczyk, 2008). However, Giroux (2011) questions the policy of having the majority of the instructors at higher education as part-timers and considers it a symptom of the crisis in the "market-driven" education which has crucial political, social, ethical, and spiritual consequences. He contends that that this policy diminishes and weakens the possibility of higher education to function as a democratic public sphere in which academics are engaged public intellectuals, and students' critical citizens. Giroux argues that within the prevailing neoliberal ideology that is dominant in American higher education, "faculty have been reduced to the status of part-time and temporary workers, comprising a new subaltern class of disempowered educators" (p. 10). He explains, "Faculty become just another reserve army of cheap laborers, a force that can be eagerly exploited in order to raise the bottom line while disregarding the rights of academic labor and the quality of education that students deserve" (p. 10). This, according to Giroux, might interfere with "educating students as critical citizens rather than as potential employees of Wal-Mart, or affirming faculty as scholars and public intellectuals who have a measure of both autonomy and power" (p. 10). The 'adjunct crisis' is believed to be simply part of a broader project that is working on changing the historical principles of higher education, through producing "an 
environment in which adjuncts outnumbering tenure-stream faculty nearly three to one is the norm" ("How to fix the adjunct crisis," 2018).

Moreover, this unchecked increasing demand for adjuncts came without much realization of their rights which made them work with a "shameful lack of support" (Lyons, 2007, p. 1). Adjunct faculty, due to the temporary nature of their employment, are often deprived of professional development. German (1996) suggested that "the use of part time faculty has grown without much guidance, mushrooming in an atmosphere of benign neglect. Relatively little time or emphasis is placed on the development of part time faculty" (as cited in Bojarczyk, 2008, p. 15). This negligence and marginalization has resulted in having adjuncts covered by "cloak of invisibility" academically speaking (Erdman, 2011, p. 7) which has profoundly impacted their professional lives and identities.

\subsubsection{Context and Professional Identity}

Adjunct faculty identity is shaped and reshaped in the context that has power in integrating or marginalizing them. It is argued that identity is not context-free but is crucially related to social, cultural, and political contexts. Tsui (2007) argues that the professional context shapes teacher identity. Moreover, Bourdieu suggests that the structural features of the social world play a crucial role in identity formation (as cited in Clarke et al., 2013) because the struggles that people go through within the boundaries of those structures to legitimately enter the social world impact the development of academic and professional identity (Clarke et al., 2013). Thus, it is critical to recognize that teaching institutions are not merely neutral settings in which educational practices are implemented but are powerful places that function as the frameworks that create and sustain meanings and values. They are the sociocultural terrain in which teaching is thought about, carried out, and evaluated (Day, 2007). Therefore, if adjuncts are deprived from being legitimate participants in the context of their work, they will develop feelings of powerlessness and alienation.

Freeman and Johnson affirm that "the notion of work context has been recognized as central in shaping teachers' perceptions of their profession" (1998, p. 400). Henkel argues that the elements of individual identity of the professional are matured through the processes of professional education and experience as the individual is embedded in a community that has its own conceptual structure, history, values, traditions, and practices. This means that professional identity is both individual and social, so that people are not only stronger because of their expertise and their own moral and conceptual frameworks, but also because they are performing a range of roles which are strongly determined by the communities and institutions of which they are members (as cited in Clarke et al., 2013, p. 9). This view is shared by Hong (2010) who stresses on the importance of context in shaping "identity [that] is continually being formed and reformed through the way we internalize the external environment, negotiate interactions, and externalize ourselves to others" (p. 1531). Thus, the adjuncts' professional identity in the Department of Writing Studies is shaped in the context of their work which is so important because, as Cojocnean points out, "the influence of workplace, negative or positive, can play a very important role in shaping teachers' identity; it can both facilitate or prevent professional development” (p. 5).

Teacher's relation with colleagues plays an essential role in identity formation. Duff and Uchida (1997) suggest that teachers' construction, conceptualization, and interrogation of their identities and practices cannot be fully understood without reference to their colleagues and students, "who together with them, co-construct their identities and communities of practice" (p. 453). In an atmosphere of lack of collegiality, adjuncts will most likely feel inferior and marginalized if they don't work with full time faculty to negotiate their identities and ideologies. This negotiation of identities and ideologies "depend[s] in large measure upon institutional and interpersonal contexts in which individuals find themselves, the purposes for their being there, and their personal biographies" (Duff \& Uchida, 1997, p. 452). When teachers' identities and beliefs seem to conflict with those of their colleagues, students or local cultures, problems may arise (Duff \& Uchida, 1997). Reynolds (1996) emphasized that what surrounds the teacher, what others expect from him, and what he allows to impact on him greatly affect his identity as a teacher. She noted that the teachers' workplace is a 'landscape' which can either be very persuasive or very demanding, or as it is the case in most contexts, very restrictive (as cited in Cojocnean, 2013). Thus, it is critical to understand, and learn how the dynamics of these powerful environments shape the way "in which some actions and ways of being are valued and encouraged whereas others are downplayed, ignored, and even silenced" (Freeman \& Johnson, 1998, p. 409).

\subsubsection{Adjunct Faculty Professional Development in Relation to Their Identities}

Collinson et al. suggest that the twentieth century has marked a new conceptual revolution which has reframed people's understandings of change. Modernist concepts of certainty, natural laws and order have been replaced with post-modern concepts such as unpredictability, interdependence, and constructed perspectives. This shift in 
thinking has envisioned new systems that can be described as transformative and self-regulating in a chaotic and turbulent environment in which the teacher's role is transformative and learning is meaning-making adventure (Collinson et al., 2009). This change suggested that teachers along with principals and groups within the organization "require continuous learning as well as opportunities to engage in dialogue and inquiry to create new knowledge, ... to work collaboratively; disseminate their learning, and contribute to their own, their colleagues, and the organization's continuous improvement" (Collinson \& Cook, as cited in Collinson et al., 2009, p. 4).

Moreover, the continuous professional development of adjuncts is a must. Leslie and Gappa suggested that "the quality of [adjuncts'] teaching shows no significant difference from that of full-timers in spite of little support" (as cited in Lyons, 2007, p. 3). "Why then," Lyons wonders, "are part-timers so much less likely than full-time faculty members to receive the professional development and other forms of support that we all realize is required for success?" (p. 2). If adjunct faculty in the DWS at the university, the context of the study, form an integral part of the teaching cadre in higher education, and if their teaching is "in a position to influence significantly the structure, direction, and quality of higher education" (Bojarczyk, 2008, p. 2), their professional development should not be ignored on the basis that they are temporary fillers whose contracts are not tenured and whose existence is contingent upon enrollment. They are, at the end of the day, faculty members who teach students and contribute to the reputation of the institution they work in.

Bojarczyk professes that the academic institutions should ensure that every faculty member should be skilled in the role of educator. Smith and Wright (2008) confirm that faculty, all faculty, "are the front-line guardians of institutional quality" (as cited in Bojarczyk, 2008, p. 10). It is therefore in academia's best interest to openly acknowledge adjunct faculty extensive presence by considering their preparation, shaping and polishing (Bojarczyk, 2008) through professional development. Smith, Butner, Cejda, and Murray (2000) contend, "Once hired, oriented, and involved in development activities, part-time (adjunct) faculty will represent a valuable resource in any department" (as cited in Bojarczyk, 2008, p. 4). However, if they are ill prepared to perform their teaching roles, Strom-Gottfried and Dunlap (2004) warn, adjunct faculty may be less comfortable and less satisfied performing these roles which leads to classroom difficulties and attrition (as cited in Bojarczyk, 2008).

Professional identity is considered a critical component in teachers' professional development and in their sociopolitical and sociocultural landscape of the classroom (Tsui, 2007). MacLure points out that "the notion of development comes to be applied, not only to professional practice or public conduct, but to identity itself, which is held to be in a state of suspension-waiting to be recovered, restored, integrated or emancipated" (p. 321; Italics added). This shows that professional development contributes in crystallizing, shaping and forming adjuncts' identity which is, as mentioned earlier, in a state of continuous change and modification. Hong (2010) suggests that "professional development programs play a critical role in building teachers' professional identity" (p. 1540). He stresses that these programs can help teachers increase awareness of the significance of emotions, and prompt them to reflect on their professional identity formation. These programs, as Hong suggests, should also "focus on the long-term agenda of establishing their professional identity" (Hong, 2010, p. 1541). Therefore, adjunct faculty in the DWS need professional development to enhance their understanding of their selves as professionals.

\subsection{Research Design}

A preliminary review of literature indicates that professional identity is an asset in teachers' professional lives and development. It also reveals that professional identity is an ongoing process which indicates that professional development can shape and impact it. This study was conducted in a university in the United Arab Emirates in the Department of Writing Studies in the College of Arts and Sciences which, as many other departments in the university, hires adjuncts to teach every semester. These adjuncts' professional lives and identities have not been explored or investigated. This study is interpretive in nature with an exploratory methodology. The interpretive approach is appropriate because the aim of the study is to explore and understand a particular phenomenon through the eyes of the participants. The study is conducted to explore adjunct faculty understanding of their own professional identity and the extent to which their professional development and contextual factors as well as their working conditions affect their identity. The study aimed to answer the following research questions:

1) How do adjuncts perceive their professional identity?

2) What institutional professional development do they receive?

3) How does the presence or absence of professional development affect their professional identity? 


\section{Method}

\subsection{Semi-Structured Interviews}

Semi-structured interview is the sole data collection method used in this study. It is a qualitative study that aims to explore and examine the professional identity of the participants as they see it. The interview is the most prominent tool for data collection in qualitative research. It is very good for "assessing people's perceptions, meanings, definitions of situations and constructions of reality" (Punch, 2009, p. 144). Kelchtermans' conceptualization of self-understanding and its five components with Lasky's vulnerability formed the basis of the interview questions. Two interviews were face to face interviews while two were conducted via Skype. Follow-up questions were conducted via Skipe with all participants to further clarify some of the points they mentioned in the interviews.

\subsection{Participants}

In such an interpretive study, "the participants' views of the situation being studied" form the lens through which the research is conducted (McKenzi and Knipe, 2006). I contacted the six adjuncts who were all ready to participate in the study. Due to the scope of the study, four of them were interviewed to gain insight into their perception of their professional identity and development. All participants have MA in TESOL. They are from different nationalities. Their teaching experience in the department of Writing Studies ranges from two to three years. Three of them had no prior experience in teaching. Their age bracket is 24-36. All adjunct faculty teach two sections which means six hours of teaching per week. All the interviewed adjuncts work only in the university where the study was conducted. They don't hold any other position or teaching job somewhere else. The six adjuncts that are hired by the DWS are females.

\subsection{Data Analysis}

Qualitative data analysis involves "making sense of data in terms of the participants' definitions of the situation, noting patterns, themes, categories and regularities" (Cohen et al., 2000, p. 461). First, all interviews were recorded, transcribed, and then categorized into the main themes that emerged from the interviews. During the interview, I condensed the meanings expressed by the interviewers into briefer statements, clarified them by sending them back to the interviewer until I made sure he or she had one possible interpretation for the sake of accuracy and transparency (Kvale, 2006). Then, the transcribed interviews were structured and clarified by eliminating repetitions and redundancies. After the transcription phase, I sent the interviewees their transcribed interview to give them the chance to comment on the interpretations made and to elaborate on their own original statements if they would like to. Kvale (1996) suggests that analysis involves "developing the meanings of the interviews, bringing the subjects' own understanding into the light as well as providing new perspectives from the researcher on the phenomena" (p. 189). Bracketing and coding interview data were then done to identify the major themes. Bracketing means suspending the researcher's meaning and interpretations to enter into the world of the unique interviewed individual to understand what the interviewee is saying rather than what the researcher expects him or her to say (Cohen et al., 2000). These themes were selected based on the recurrence of ideas in the participants' answers, keeping in mind the research questions. Data analysis was guided by research question, as "it draws together all the relevant data for the exact issue of concern to the researcher" to close the loop on the research questions that were raised in the early part of the study (Cohen et al., 2000, p. 471).

\subsection{Ethical Dimensions}

All participants signed the consent forms. They were all assured confidentiality and that their names or identities would not be revealed. I explained to them that they can withdraw from the study any time they want to. Pseudonyms are used to conceal their identities. Their nationalities cannot be revealed because they might lead to their identities due to the small number of adjuncts teaching in the Department. In the interpretive paradigm, the positivist notion of validity is replaced with the notion of authenticity and credibility (Guba, \& Lincoln, as cited in Cohen et al., 2000) which was assured through reporting the situation through the eyes of the participants, and obtaining data that are rich, deep, honest, and through the appropriate choice of methods, and appropriate treatment of data (Cohen et al., 2000). Because research is context-bound, comparability and transferability replace generalizability as criteria for the external validity (Cohen et al., 2000). Thus, "the data and the findings are not used for generalizations but for deep understanding.... However, readers of research can draw similarities between a study and educational context" (Troudi, n. d).

\section{Results}

Results are presented and discussed under the following sections: a) adjunct faculty identity components, b) adjunct faculty professional development, and c) access and denial of access. 


\subsection{Adjunct Faculty Identity Components}

Results show that adjunct faculty suffer from identity dilemma that has affected their self-esteem, task perception, job motivation and future perspectives.

\subsubsection{Self-Image}

The interviewed adjuncts are having problem making sense of their identity. Their self-image is blurred and contradictory. While they perceive themselves as "qualified teacher[s] who love teaching," they feel that they are perceived by administrators as "the last-minute shelter" while being "underestimated" by full timers who consider them "less professional" that themselves, as they suggested. Nora says that she feels "underestimated by superiors [full timers], superiors are not believing in you." Kathy also feels that she is "perceived as competent, but as young or immature" by full timers because she doesn't have much experience. Two adjuncts seemed affected by the way they are perceived by full timers.

Nora says,

It puts me down. When I am working on my materials, creating my syllabus, I am someone who is in control of a classroom, but when I go upstairs, I feel that whatever value I was doing here is lost. I feel like having on another persona. I don't feel the same person when I am upstairs. Whatever you are doing is not much, not important. You feel inferior.

This reference to being different person and having different persona with students and full timers might indicate a kind of schizophrenic identity experienced by Nora which is deeply affecting her self-confidence. Mary also experienced similar feelings. She said,

I feel different with my students. In the classroom, I am professor. Upstairs, I am an adjunct. This is really causing me pain. It is fluctuating. I am not sure of myself and which feeling to believe.

These shockingly double personalities might imply a sense of anomie or loss experienced by adjuncts which is an evidence of the blurry identity they have. However, two of the interviewed adjuncts expressed their indifference towards the full-timers' opinion. Farah says, "I don't see them [full timers] that much. I just teach and leave."

\subsubsection{Self-esteem}

This disturbed vision has affected their self-esteem; their sense of appreciation. Two adjuncts got negative feedback from their full-time colleagues. Kathy answered the question of whether she received negative feedback by saying, "Yes, although it wasn't about my teaching. It made me distrust the people I work with." Mary said that she once received a negative feedback that affected her self-esteem deeply. She said, "I received an email from a full timer. It was a very harsh email that made me feel like a misbehaving child rebuked by an elder."

Moreover, interviewed adjuncts have a bitter sense of absence of appreciation. The absence of appreciation from administration made them seek emotional support from students. They revealed that appreciation of their work from administration was rare and didn't transcend the level of nice words. All four participants declared that students made them feel good about themselves. Adjuncts had a very high self-esteem in the classroom. They all expressed their happiness with their students' feedback which reflected appreciation and content. Farah says, "I feel more from my students. I don't see others. My only indication of appreciation from the administration is that I am hired again." Mary also expressed her satisfaction and substitution for the gratitude she receives from the students. She explains, "My students like me and appreciate my work and that is what matters." Kathy says, "Students really matter. They give me hope."

However, this content with students' perception is threatened. The four interviewed adjuncts shared their fear of losing this good image upon students' recognition that they are adjuncts. Farah said,

In class, I introduce myself to my students that I am instructor without reference to being adjunct. Students do not know that I am adjunct most of the time. I feel that if they knew that I am adjunct, they would think I need their evaluation, or that they have power over me.

Nora says,

Once I encountered a case when a student came to my office, and said, 'you are adjunct!' He looked disgusted. I wonder why they have "adjunct faculty" plate at the door of my office. It makes me look as an insect... I just maneuver around and not tell them I am an adjunct because this will affect them negatively. 
They will consider they are not taught by professional instructor. They think if I am professional enough, I would have been hired as full timer.

Kathy stated, “I don't think my students know I'm an adjunct. I didn't want them to know I am an adjunct. Probably they wouldn't have taken me as seriously. Maybe they wouldn't have thought I was as competent to teach them." This fear of being known as adjuncts by their students shows that adjuncts do not have self-esteem of being adjuncts. They hide their identity from their students which is increasing their identity dilemma.

\subsubsection{Task Perception}

Self-esteem is intertwined with task perception. As Kelchtermans suggests, when teachers perceive themselves as proper teachers, they will have self-esteem. Adjuncts are not sure about themselves because they are sent different messages about their job. They feel that they are good teachers who should be equal to full timers. They feel that they are "competent" and "qualified" to teach. However, they don't feel that they are perceived as proper teachers by administrators and full timers who perceive them as "inferiors" and "less professional" which is affecting their task perception. Moreover, their fear of students' realization that they are adjuncts shows that they do not perceive being an adjunct as good instructor.

\subsubsection{Job Motivation}

The four interviewed adjuncts have one basic motivation to work as adjuncts which is getting full time job. However, they don't see that they will eventually be full timers in the Department which is affecting their motivation. Kathy says, "I saw being an adjunct as a first step. Most full-time teachers I know in the university started as adjuncts, either at AUS or another school." This motivation lessened with time. Kathy then realized that her dream of getting full time job cannot be realized. She says, "I would like to continue teaching writing. But I don't think I will get a full-time job at a good university unless I have a PhD."

\subsubsection{Future Perspectives}

The four interviewed adjuncts share the uncertainty and the fear of what future may hold for their academic life. They are even frightened by "who is next?" as Mary says in reference to the adjuncts who are dismissed every semester. She says, "Last Fall, we were eleven adjuncts. This semester, we are six. I don't feel secure. I feel I have no future here."

Nora says,

I don't see that bright future. The new rules [that adjuncts should not teach more than two courses] are making our lives harder. Teaching two courses! They want us to work in four universities to have a proper income. You want me to jump here and there. All this is demotivating me.

This lack of hope also springs from feeling unsecure. Nora adds, "I don't have security at all. I am always on my nerves. Every semester we don't know what we will teach until one or two days before classes start. It is just making our life harder and more stressful."

\subsubsection{Vulnerability}

Adjuncts feel vulnerable in class because they are afraid of revealing their real identity as adjuncts. Adjuncts do not open with their colleagues because they are afraid of being looked at as incompetent. All interviewed adjuncts suggested that they don't want to ask for help because they don't want to look incompetent or unqualified. Farah said, "I didn't want to bother anybody. It was my first experience. So, I didn't want to show that I cannot manage things or that I cannot teach or something, so I wanted to depend on myself more." This proves that adjuncts felt unsafe to take the risk of losing face with full timers (Lasky, 2005) which indicates that the environment was not collaborative or friendly.

\subsection{Adjunct Faculty Professional Development}

The four interviewed adjuncts agreed on the absence of professional development. They answered all the questions that asked whether they were prepared for teaching, whether they receive continuous professional development, and whether they attend meetings or represented in them by "No." Kathy summarized the whole situation of adjuncts when she said, "No one cares what adjuncts are doing." Kathy talked about her first semester with a sigh saying, "It was extremely difficult. I had no life that semester. It was my first semester teaching, so everything was new, and I had to develop my own systems as a teacher."

Adjuncts expressed their need to have professional development. In their response to the question of what areas they wanted these programs to focus on, if given professional development programs by the department, interviewed adjuncts showed an array of needs. While Mary and Farah emphasized the need for training on using 
technology, Nora wanted to have workshops on the syllabus and the related readings. Kathy said that the assessment is not clear and not consistent. She said, "I don't think there is very much consistency in how instructors grade. We also need to be told what the curriculum is. Again, I don't think the instructors follow the same curriculum." This shows that there should be an assessment of the adjuncts' needs before designing any professional development programs.

What makes this lack of professional development and training more dangerous is the freedom adjuncts have in designing their materials. All interviewed adjuncts expressed their joy of having the freedom of teaching they way they like, in designing their syllabus and choosing their materials. However, this freedom came without guidance and supervision which might threaten the quality of teaching especially that most of interviewed adjuncts didn't have prior experience in teaching and didn't get help upon their appointment. This is proved by their response to the question about their student evaluation in their first semester and the effect of lack of orientation and professional development on it. Farah said that the comments she got in her student evaluation helped her improve her teaching in the absence of any other feedback. Mary said, "My student evaluation was not good and when I think of it, I feel sorry for the students who had to go with me in the process of discovering the syllabus and the objectives of the course." Kathy commented saying, "They improved over time as I gained confidence. By the third semester I was happy with my evaluations." This might indicate that the evaluations of the two first semesters were not very good. Having professional development would have saved the adjuncts the journey of discovering what they should do on their own and would not have affected the quality of teaching.

\subsection{Access and Denial of Access}

Three of the four interviewed adjuncts revealed that they don't feel part of the institution while one said she does. Nora said, "No. from the way everything happens, from the way you are always on the waiting list. No security, I don't feel that I belong to the family here even though there are good people." She expressed her wish to be allowed to, saying, "Of course! I wish to feel part of the place. It can be achieved by having security. The adjunct who considered herself part of the institution gave reasons that have nothing to do with her professional life as an instructor. Living on campus was the reason for this feeling due to having her parent full timer. Kathy said, "I feel part of the institution because I have many friends who are full timers, even outside DWS. I would be invited to parties." This shows that adjuncts do not feel part of the professional context and are not allowed to.

\section{Discussion}

The findings of the study were in line with the literature that suggests that adjunct faculty are often not prepared for their teaching job. Curtis and Jacobe (2006) suggested that the nature of the adjuncts' hiring process makes it impossible for them to prepare adequately for teaching. They explain that adjuncts are usually "considered last when developing course schedules for an academic term, since they are viewed primarily as "filling in the gaps"” (p. 8). This leaves them with few weeks or day to be prepared which makes them unable to plan ahead on what topics to cover, or what methods to use (Curtis \& jacobe, 2006). This was the case with the four interviewed adjuncts who expressed their panic and fear because they had to start teaching without being prepared.

The findings also showed an array of needs which necessitates an institutional sensitivity to the needs of adjuncts. These needs are varied and personal because adjuncts constitute a diverse lot; an extremely heterogeneous group whose reasons for teaching are varied and life experiences and training are also different (Bojarczyk, 2008). Because of this diversity and heterogeneity in their needs and requirements, the programs of professional development should first assess their needs, and then establish programs and activities to meet them (Bojarczyk, 2008).

New adjuncts "require effective integration, socialization, and enculturation into their specific higher education environments" (Bojarczyk, 2008, p. 3). They need to be prepared for their teaching jobs. They should not be thrown all of the sudden in their classrooms. Day contends that "teachers will only be able to fulfill their educational purposes if they are both well prepared for the profession" (p. 2) because "conflicts or dissonance experienced at such moments might have negative consequences" (Pearce \& Morrison, 2011, p. 49). Pillen et al. (2013) suggested that when beginning teachers enter the teaching profession, they bring with them their own conceptions of teaching and learning which are drawn from their prior experiences. At the same time, the context of their work exposes them to a great number of different expectations from students, school leaders, colleagues, and parents. Thus, teachers feel the necessity to adapt to the demands that come with their teaching profession; to reconcile their personal and professional sides of becoming a teacher. Their ability to do this reconciliation characterizes and determines the development of their professional identity (Pillen et al., 2013). The authors emphasize that in order to help beginning teachers overcome feeling frustrated in learning to teach, "they should not be left to cope on their own with their professional identity tensions" (Pillen et al., 2013, p. 87). They need 
institutional support and institutional awareness of their professional identity tensions (Pillen et al., 2013).

The findings of this study also show that adjuncts do not have any sense of security which is affecting their identity. Day (2007) stresses that stability of employment and status has been always the hallmark of teaching while instabilities create stresses in the fabric of identity. He argues that teachers need to be supported in ways that sustain positive identities and effectiveness. Kelchtermans also contend that job stability; the need to maintain the status quo and achieve ambition, leads to job satisfaction while vulnerability leads to teachers' passivity and conservatism in teaching (as cited in Day, Kington, Stobart, \& Sammons, 2006). Adjuncts feel unsecure because, as Curtis and Jacobe suggest, there is no employment guarantee beyond one semester which means that reappointment is a possibility. Not only that, sometimes when adjunct faculty are assigned to teach a section that might get cancelled the last minute due to low enrolment or that the section is taken by a full timer who needs to complete his assignment. This might leave adjuncts jobless because they cannot secure another job (Curtis \& Jacobe, 2006).

Findings show that DWS adjuncts are not invited to department meetings and are not represented in them which increase their spatial alienation and exclusion due to having their offices in the basement. Literature suggests that teachers should feel that they are active members in the community of practice in which they share understandings about what they do and what that means in their lives and for their communities because learning occurs when people participate in activities where they become increasingly active participants (Varghese et al., 2005). Learning is an evolving form of membership which lies at the heart of co-participation. Access is crucial to 'legitimate participation,' as Varghese et al. observe. In the same time, "when access is denied, knowledge can become abstract, making meaning less visible and more difficult to see" (p. 30). Tsui believes that "participation is central to identity formation. Thus, teachers should be afforded legitimacy of access to practice and opportunities for developing professional competence and having their competence recognized" (2007, p. 678). Yates (2017) suggested that full-time faculty can positively impact adjunct faculty status by "making connections with adjuncts who may be teaching courses the full-time faculty have designed and inviting them to collaborate on course design and updates" (p. 93).

The findings came in line with literature in regard to adjuncts isolation. Curtis and Jacobe suggest that adjunct faculty "teach in isolation" $(2005$, p. 9). They are not allowed to participate in departmental meetings and do not have a say on academic issues because they are not represented in institutional decision-making bodies. This exclusion of adjunct faculty "clearly represents a substantial limitation on their functioning as a faculty" (Curtis $\&$ Jacobe, 2006, p. 9). It is also clear from the results that adjuncts have not developed shared identity which comes as result of a sense of common experiences, understandings and expertise, and shared ways of perceiving problems and their possible solutions, as suggested by Evetts (2012). These elements are absent from the interviewed adjuncts' professional lives due to their exclusion, alienation, and denial of access. Seliger (2015) contends that the ongoing professional development fosters the teaching identity, leads to higher satisfaction, and reduces adjuncts' isolation while the lack of professional development leads to a reduced commitment to the adjunct role.

Findings also showed that adjuncts do not feel that they have job equity with their full-time colleagues. Job equity is one of the essential elements that should be emphasized in educational settings. Hargreaves suggests that "all teachers are held to have rights to professional development, and opportunities must be distributed equitably" (as cited in Day, 2007, p. 430). However, adjuncts do not enjoy this sense of equity because they are viewed as 'second-class citizens' who have lower status that full-time faculty. Whitfield (2011) points out that "job equity is an ongoing issue and does contribute to the demoralized status of adjuncts everywhere" (p. 107) which results in making them "feel alienated, powerless and invisible" (Bojarczyk, 2008, p. 50). One form of this inequality is the spatial one which has emotional impact on both faculty and students (Nelson, 2011) as it is clearly evident in the study. Adjuncts' offices are located in the basement which is causing them embarrassment and feeling of inferiority. This has been proved by Nelson who emphasizes that the spatial transience in relegating adjuncts to cubicles or shared offices not only impacts adjuncts negatively and causes emotional anxiety but also communicates to their students that adjuncts are academically less qualified than full time instructors. Nelson explains that adjuncts, in relation to their colleagues and students, experience "feelings of ontological and epistemological inadequacy; they feel themselves to be lesser beings and are often treated as inadequate" (Nelson, 2011, p. 27).

\section{Conclusion}

It is clear that adjuncts have dilemma with their professional identity because of the contradictions in the messages sent to them in their work environment. The absence of professional development increases this 
dilemma as they are left to struggle on their own. Adjuncts need to have continuous professional development chances, to feel part of the institution they work in, to be prepared for teaching, and to be considered as valued members in the community of practice by inviting them to meetings, explaining the policy of the department, and having their voices heard.

\section{Acknowledgments}

I would like to thank the provost and the dean of the faculty of Communication, Arts and Sciences at the Canadian Universisty of Dubai for their continuous support and encouragement for doing research and disseminating knowledge through publications and presentations. I would also like to thank the adjuncts who opened their hearts in the interviews. This paper would not have seen the light without their contribution.

\section{References}

Beijaard, D., Meijer, P. C., \& Verloop, N. (2004). Reconsidering research on teachers' professional identity. Teaching and Teacher Education, 20, 107-128. https://doi.org/10.1016/j.tate.2003.07.001

Bojarczyk, H. (2008). Faculty development activities for new adjunct faculty: A qualitative investigation of which types of activities most benefit new adjunct faculty at four-year colleges and universities. (Doctorate thesis). Oakland University, Michigan, USA.

Clandinin, D. J., \& Connelly, F. M. (1996). Teachers' professional knowledge landscapes: Teacher stories. Stories of teachers. School stories. Stories of schools. Educational Researcher, 25(3), 24-30. https://doi.org/ $10.2307 / 1176665$

Clarke, M., Hyde, A., \& Drennan, J. (2013). Professional identity in higher education. In B. M. Kehm, \& U. Teichler (Eds.), The Academic profession in Europe: New tasks and new challenges, The changing Academy- The changing Academic profession in International comparative perspective. Dordrecht: Springer. https://doi.org/10.1007/978-94-007-4614-5_2

Cohen, L., Manion, L., \& Morrison, K. (2011). Research Methods in Education. Routledge Falmer: London.

Collinson, V., Kozina, E., Lin, Y. K., Ling, L., Matheson, I., Newcombe, L., \& Zogla, I. (2009). Professional development for teachers: A world of change. European Journal of Teacher Education, 32(1), 3-19. https://doi.org/10.1080/02619760802553022

Cojocnean, D. (2013). Shaping and reshaping a 'professional identity' in a private school context. Academia Science Journal, 2(3), 3-12.

Curtis, J. W., \& Jacobe, M. F. (2006). Consequences: An increasingly contingent faculty. The Contingent Faculty Index 2006. American Association of University Professors. AAUP.

Day, C. (2007). Teachers matter Connecting work, lives and effectiveness. Buckingham, GBR: McGraw Hill Education.

Day, C., Kington, A., Stobart, G., \& Sammons, P. (2006). The personal and professional selves of teachers: Stable and unstable identities. British Educational Research Journal, 32(4), 606-616. https://doi.org/10.1080/ 01411920600775316

Duff, P. A., \& Uchida, Y. (1997). The negotiation of teachers' sociocultural identities and practices in postsecondary EFL classrooms. TESOL Quarterly, 31(3), 451-486. https://doi.org/10.2307/3587834

Erdman, R. R. (2011). The incredible invisible adjunct. In S. M. DeSantis (Ed.), Academic apartheid: Waging the adjunct war. Cambridge: Cambridge Scholars Publishing.

Evetts, J. (2006). Short note: The sociology of professional groups: New directions. Current Sociology, 54, 133.

Evetts, J. (2012). Professionalism in turbulent times: Changes, challenges and opportunities. Propel International Conference: Stirling.

Feldman, D. C., \& Turnley, W. H. (2004). Contingent employment in academic careers: Relative deprivation among adjunct faculty. Journal of Vocational Behavior, 64, 284-307. https://doi.org/10.1016/j.jvb. 2002.11.003

Freeman, D., \& Johnson, K. E. (1998). Reconceptualizing the knowledge-base of language teacher Education. TESOL Quarterly, 32(3), 397-417. https://doi.org/10.2307/3588114

Gappa, J. M. (2008). Today's majority: Faculty outside the tenure system. Change: The Magazine of Higher Learning, 40(4), 50-54. https://doi.org/10.3200/CHNG.40.4.50-54 
Giroux, H. A. (2011). On critical pedagogy. Continuum International Publishing Group: New York.

Hargreaves, A. (2005). Educational change takes ages: Life, career and generational factors in teachers' emotional responses to educational change. Teaching and Teacher Education, 21, 967-983. https://doi.org/ $10.1016 /$ j.tate.2005.06.007

Hong, J. Y. (2010). Pre-service and beginning teachers' professional identity and its relation to dropping out of the profession. Teaching and Teacher Education, 26, 1530-1543. https://doi.org/10.1016/j.tate.2010.06.003

Kelchtermans, G. (2009). Who I am in how I teach is the message: Self-understanding, vulnerability and reflection. Teachers and Teaching: Theory and Practice, 15(2), 257-272. https://doi.org/10.1080/13540600 902875332

Kelchtermans, G. (2005). Teachers' emotions in educational reforms: Self-understanding, vulnerable commitment and micropolitical literacy. Teaching and Teacher Education, 21, 995-1006. https://doi.org/ $10.1016 /$ j.tate.2005.06.009

Korkki, P. (2018). Adjunct professors step out their efforts to increase pay. The New York Times. Retrieved from https://www.nytimes.com/2018/04/05/education/learning/adjunct-professors.html

Kvale, S. (2006). Dominance through interviews and dialogues. Qualitative Inquiry, 12, 480-500. https://doi.org/ $10.1177 / 1077800406286235$

Kvale, S. (1996). Interviews: An introduction to qualitative research interviewing. Thousand Oaks California: Sage Publications.

Lasky, S. (2005). A sociocultural approach to understanding teacher identity, agency and professional vulnerability in a context of secondary school reform. Teaching and Teacher Education, 21(8), 899-916. https://doi.org/10.1016/j.tate.2005.06.003

Lyons, R. E. (2007). Deepening our understanding of adjunct faculty. In R. E. Lyons (Ed,). Best practices for supporting adjunct faculty (pp. 1-12). Bolton, Massachusetts, USA: Anker Publishing Company.

MacLure, M. (1993). Arguing for your self: Identity as an organizing principle in teachers' jobs and lives. British Educational Research, 19(4), 311-322. https://doi.org/10.1080/0141192930190401

Mackenzie, N., \& Knipe, S. (2006). Research dilemmas: Paradigms, methods and methodology. Issues In Educational Research, 16, 4-14.

Magness, P. W. (2017). Are full-time faculty being adjunctified? Recent data show otherwise. James G. Martin Center for Academic Renewal Comment Policy. Retrieved from https://www.jamesgmartin. center/2017/05/full-time-faculty-adjunctified-recent-data-show-otherwise/

Nelson, H. F. (2011). The subaltern in academia: Advancing an ethos of equity. In S. M. DeSantis (Ed.), Academic apartheid: Waging the adjunct war (pp. 27-30). Cambridge: Cambridge Scholars Publishing.

Nias, J. (1996). Thinking about feeling: The emotions in teaching. Cambridge Journal of Education, 26(3), 293-306. https://doi.org/10.1080/0305764960260301

Pearce, J., \& Morrison, C. (2011). Teacher identity and early career resilience: Exploring the links. Australian Journal of Teacher Education, 36(1), 48-59. https://doi.org/10.14221/ajte.2011v36n1.4

Pillen, M. T., Den Brok, P. J., \& Beijaard, D. (2013). Profiles and change in beginning teachers' professional identity tensions. Teaching and Teacher Education, 34, 86-79. https://doi.org/10.1016/j.tate.2013.04.003

Punch, K. F. (2009). Introduction to research methods in education. Los Angeles: Sage Publications.

Simon-Maeda, A. (2004). The complex construction of professional identities: Female EFL educators in Japan speak out. TESOL Quarterly, 38(3), 405-436. https://doi.org/10.2307/3588347

Seliger, J. D. (2015). The role of professional development in adjunct nursing faculty identity salience. Unpublished $\mathrm{PhD}$ Thesis: Iowa State University. Retrieved from https:/lib.dr.iastate.edu/cgi/ viewcontent.cgi?referer $=\&$ httpsredir $=1 \&$ article $=5514 \&$ context $=$ etd

Thomas, L., \& Beauchamp, C. (2011). Understanding new teachers' professional identities through metaphor. Teaching and Teacher Education, 27, 762-769. https://doi.org/10.1016/j.tate. 2010.12.007

Tsui, A. B. M. (2007). Complexities of identity formation: A narrative inquiry of an EFL teacher. TESOL Quarterly, 41(4), 657-680. https://doi.org/10.1002/j.1545-7249.2007.tb00098.x

Troudi, S. (n.d). Paradigmatic nature and theoretical framework in educational research. Retrieved from 
https://education.exeter.ac.uk/ojs/index.php/inspire/ article/view/25

Varghese, M., Morgan, B., Jonston, B., \& Johnson, K. A. (2005). Theorizing language teacher identity: Three perspectives and beyond. Journal of Language, Identity, and Education, 1(4), 21-44. https://doi.org/10.1207 /s15327701jlie0401_2

Whitfield, P. (2011). 'Sucking Hind Tit': Adjuncts and access in the community college. In S. M. DeSantis (Ed.), Academic apartheid: Waging the adjunct war (pp. 99-108). Cambridge: Cambridge Scholars Publishing.

Yates, S. D. (2017). Love, honor, and "light bulbs": Investigating adjunct faculty identity and preparation for online teaching at a southeastern research university. Unpublished $\mathrm{PhD}$ thesis. The University of Alabama: TUSCALOOSA, ALABAMA.

\section{Appendix A}

\section{Interview Questions}

1. Name

2. Age

3. Degree

4. Years of experience

5. Years of teaching at the university

6. How many classes do you teach?

7. What level?

8. How do you see yourself as an adjunct? How do full timers and administrators perceive you?

9. Can you describe teaching in the first semester?

10. How was the student evaluation? How did it improve later?

11. Do you see that your work is appreciated by others in the department? What is the evidence for this appreciation or lack of it?

12. Do you usually receive feedback from administrators and colleagues on your work?

13. Have you ever received any negative feedback? How has it affected the way you perceive yourself and your work?

14. Do you feel that you and your colleagues have equality?

15. Does anything in the department make you, as adjunct, feel less than full timers academically?

16. Are you usually invited to meetings or workshops?

17. Are you represented as adjuncts in the department meetings?

18. What kind of professional development did you receive when you started working here?

19. What kind of ongoing institutional professional development are you offered? nothing

20. Do you use your own materials, or you have a textbook that you need to use?

21. Do you have freedom in setting your own syllabus?

22. How are you perceived as an adjunct by your students?

23. Do you feel that your students feel that you are less qualified than full timers? What might send them messages about your being less than full timers?

24. Do you share the same physical place with full time faculty?

25. Have you received any training on using technology?

26. If you were given professional development programs by the department, what are the areas that you want these programs to focus on?

27. Do you face difficulty with using technology in classroom?

28. Do you feel that you are part of the institution you work in? 
29. What are your prior experiences or beliefs that you think contradict with the educational policy but you need to abide by?

30. What are your motivations to keep working as part timer?

31. How do you see your future at AUS?

32. What future perspectives do you have?

\section{Copyrights}

Copyright for this article is retained by the author(s), with first publication rights granted to the journal.

This is an open-access article distributed under the terms and conditions of the Creative Commons Attribution license (http://creativecommons.org/licenses/by/4.0/). 